\title{
O KONSTRUKCJI NIEDOPUSZCZALNOŚCI CZYNNOŚCI KARNOPROCESOWEJ
}

I. W procesie karnym, którego kształt podlega nieustannym zmianom, szczególnie cenne są takie konstrukcje prawne, które umożliwiaja prowadzenie badań nad jego modelem, oraz takie, które pozwalają uchwycić istotne cechy poszczególnych instytucji prawa karnego procesowego. W ramach analiz ujmujacych proces karny w sposób dynamiczny bez wątpienia taki właśnie charakter ma konstrukcja niedopuszczalności czynności karnoprocesowych ${ }^{1}$. Aktualnie, gdy polskie prawo karne procesowe przechodzi kolejną istotna przemianę, wynikająca z nowelizacji k.p.k. z 27 września 2013 r. ${ }^{2}$, podjęcie próby określenia charakteru tej konstrukcji jest w pełni uzasadnione. Ujęcie przedstawione w niniejszym szkicu zostanie osadzone w kontekście dotychczasowych badań związanych z konwencjonalnym charakterem czynności karnoprocesowych ${ }^{3}$. W związku z tym w pierwszej kolejności, niejako jako wprowadzenie do rozważań, zreferowany zostanie w skrócie stan dotychczasowych badań.

II. Podstawowe znaczenie dla ujęcia konstrukcji niedopuszczalności czynności karnoprocesowych ma zaproponowana przez poznańsko-szczecińską szkołę teorii prawa koncepcja czynności konwencjonalnych w prawie ${ }^{4}$. W ramach tej koncepcji ujmuje się czynności prawne jako czynności racjonalne nastawione na interpretację. Każda czynność konwencjonalna jako struktura złożona, poza jej tzw. substratem materialnym, ma także właściwe

\footnotetext{
${ }^{1}$ Jest ona kategorialnie odmienna od konstrukcji niedopuszczalności procesu karnego - zob. A. Murzynowski, Przyczynek do zagadnienia nieważności czynności procesowych wykonanych w niedopuszczalnym postepowaniu karnym, „Nowe Prawo” 1962, nr 7-8, s. 985 oraz M. Cieślak, Nieważność orzeczeń $w$ procesie karnym PRL, Warszawa 1965, s. 60 i n.; B. Janusz-Pohl, Przyczynek do rozważan o formalnym $i$ konwencjonalnym charakterze procesu karnego, „Ius Novum” 2014, z. 4.

${ }^{2}$ Ustawa o zmianie ustawy - Kodeks postępowania karnego oraz niektórych innych ustaw, Dz. U. 2013, poz. 1247.

${ }^{3}$ Zob. B. Janusz-Pohl, O wyroku nieistniejacym w procesie karnym, „Państwo i Prawo” 2013, z. 12.

${ }^{4}$ Zob. L. Nowak et al., Czynności konwencjonalne w prawie, „Studia Prawnicze” 1972, z. 33, s. 73 i n.; Z. Ziembiński, Problemy podstawowe prawoznawstwa, Warszawa 1980, s. 135-136; K. Ajdukiewicz, Logika pragmatyczna, Warszawa 1975, s. 51-53; M. Zieliński, Wyktadnia prawa. Zasady, reguty, wskazówki, Warszawa 2008, s. 28; S. Czepita, Reguty konstytutywne a zagadnienia prawoznawstwa, Szczecin 1996, s. 146 i n.
} 
jej reguły pozwalające na interpretację znaczenia substratu materialnego ${ }^{5}$. Reguły te początkowo nazywano regułami sensu ${ }^{6}$, później zaś - regułami konstrukcyjnymi ${ }^{7}$. Po uzupełnieniu badań nad czynnościami konwencjonalnymi w prawie przez Stanisława Czepitę o pochodząca z filozofii lingwistycznej koncepcję reguł konstytutywnych ${ }^{8}$ reguły te zakwalifikowano jako reguły konstytutywne. Istotna dla dogmatyk prawniczych teza wynikająca z przyjęcia wskazanej koncepcji jest następująca: czynności (zachowania się), które nie spełniają właściwych im reguł konstytutywnych nie są w konsekwencji rozpoznawane jako określone czynności karnoprocesowe. Konsekwencją naruszenia reguł konstytutywnych czynności określonego typu jest jej nieważność albo nieistnienie prawne ${ }^{9}$.

Przełomowym momentem rozwoju koncepcji czynności konwencjonalnych z punktu widzenia możliwości jej zastosowania na gruncie prawa karnego procesowego było wyodrębnienie w jej ramach mechanizmów konwencjonalizacji i formalizacji. Dla przejrzystości dalszego wywodu wskazać należy, że w prawoznawstwie przez konwencjonalizację określa się mechanizm odpowiadający za powstanie określonej czynności konwencjonalnej. Jest on zatem mechanizmem wyznaczonym przez reguły konstytutywne poszczególnych czynności konwencjonalnych w prawie (a więc również czynności karnoprocesowych). Reguły konstytutywne są zatem regułami konwencjonalizacji danej czynności prawnej (karnoprocesowej), a ich przekroczenie prowadzi do tego, że zachowanie pretendujące do bycia substratem materialnym owej czynności nie zostaje rozpoznane jako ważnie dokonana czynność określonego typu. Mechanizm formalizacji natomiast jest charakteryzowany przez pozostałe reguły określone dla czynności danego typu niebędące regułami konstytutywnymi, ale również decydujace o jej konstrukcji, których przekroczenie nie podważa bytu i ważności dokonanej czynności, lecz może wywrzeć wpływ na jej skuteczność. W tym sensie wyróżnia się formalizację przez wyznaczenie obowiązu i formalizację przez wyznaczenie konsekwencji ${ }^{10}$. Formalizacja

${ }^{5}$ Substratem materialnym czynności konwencjonalnej jest psychofizyczne zachowanie się człowieka albo też jego mniej złożona czynność konwencjonalna - zob. L. Nowak et al., op. cit., s. 78 .

${ }^{6}$ Wskazywano, że: „Reguła sensu czynności konwencjonalnej ustanawia (1) czyjej czynności psychofizycznej (względnie czyjej prostej czynności konwencjonalnej), (2) w jaki sposób i w jakich okolicznościach, w szczególności w jakim trybie dokonanej, przypisuje się (3) charakter takiego a nie innego rodzaju czynności konwencjonalnej” - Z. Ziembiński, M. Zieliński, Dyrektywy i sposób ich wypowiadania, Warszawa 1992, s. 47.

${ }^{7}$ Zob. Z. Ziembiński, M. Zieliński, op. cit., s. 46-57; S. Czepita, Wprowadzenie w: idem (red.), Konwencjonalne i formalne aspekty prawa, Szczecin 2006, s. 7-8.

${ }^{8}$ Zob. J. R. Searle, Speech Acts. An Essay in the Philosophy of Language, London 1977, s. 15 in.; S. Czepita, Reguty ..., s. 146 i n.

${ }^{9}$ Wysubtelnienia koncepcji czynności konwencjonalnych w kontekście ich nieważności dokonał T. Gizbert-Studnicki, O nieważnych czynnościach prawnych w świetle koncepcji czynności konwencjonalnych, „Państwo i Prawo” 1975, z. 4; idem, Normy celowościowe a reguty konstytutywne w prawie, w: A. Bondar (red.), Prawo a polityka. Księga pamiatkowa ku czci K. Opatka, Warszawa 1988, s. 102-112.

${ }^{10}$ S. Czepita, Formalizacja a konwencjonalizacja dziatań w prawie, w: idem (red.), op. cit., s. 60. 
i związane z nią reguły formalizacji określaja, w jaki sposób niewadliwie dokonać czynności procesowej danego typu (przy założeniu, że wadliwościa w zasadzie nie jest nieważność czynności, a kwestię owej wadliwości bada się tylko po wcześniejszym ustaleniu jej istnienia i ważności). Bazowa koncepcja ukształtowana jest bowiem na ustaleniu, że o czynnościach prawnych (procesowych) odmiennie niż o zwykłych czynnościach psychofizycznych możemy orzekać w płaszczyźnie ich skuteczności/bezskuteczności tylko po wcześniejszym stwierdzeniu ich ważności ${ }^{11}$. Ostatecznie więc zgodnie z przedstawionym już wcześniej wnioskiem to właśnie mechanizm formalizacji pozwala na prowadzenie analizy w kierunku najbardziej pożądanym dla procesualistów, tj. w kierunku badania skuteczności/bezskuteczności czynności karnoprocesowych.

III. W innym opracowaniu podjęta została już kwestia możliwych perspektyw odwołania się na gruncie procesu karnego do mechanizmów formalizacji i konwencjonalizacji ${ }^{12}$. Powołując się na teoretycznoprawne badania w obrębie prawa karnego procesowego, uznano, że rozważając proces karny z perspektywy globalnej - tj. jako całości - jego konwencjonalizacja jako określonego typu procesu prawnego jest niewątpliwa ${ }^{13}$. Proces karny stanowi bowiem konstrukcję zbliżona do układu gry, np. gry w szachy, w ramach której poszczególni uczestnicy mają im tyko przyporządkowane role i instrumenty działania, a całość rozgrywki odbywa się zgodnie z wyznaczonymi regułami ${ }^{14}$. Zaznaczono jednocześnie, że tak ogólna płaszczyzna analizy niespecjalnie przekłada się na rozstrzyganie konkretnych problemów, z jakimi spotyka się dogmatyk prawa karnego procesowego. Kluczowe zatem stało się rozstrzygnięcie kwestii, jaką rolę odgrywa konwencjonalizacja procesu analizowanego w płaszczyźnie partykularnej, a więc w odniesieniu do poszczególnych czynności karnoprocesowych. Wstępnie bowiem wydawało się, że skoro to instrument w postaci formalizacji stwarza najlepsze warunki do analizy czynności karnoprocesowych, wykorzystywanie instrumentu w postaci konwencjonalizacji w płaszczyźnie partykularnej nie ma przed sobą większych perspektyw.

Taki wniosek wydawał się prima vista uzasadniony choćby tą okolicznościa, że w obecnie obowiązujacym prawie karnym procesowym instytucja nieważności (bezwzględnej, ex tunc) czynności karnoprocesowej w ogóle nie stanowi przedmiotu regulacji prawnej. Ani jeden przepis zawarty w k.p.k. nie wskazuje, że dana czynność z uwagi na określone jej uchybienia jest czynnością nieważna. Zresztą polskie prawo karne procesowe nigdy nie

\footnotetext{
11 Zob. M. Zieliński, Wyktadnia..., s. 28.

12 B. Janusz-Pohl, Przyczynek..., s. 46.

${ }^{13}$ Zob. J. Wieczorkiewicz-Kita, Zagadnienie wyrokowania w polskim procesie karnym $w$ świetle koncepcji czynności konwencjonalnych, w: S. Czepita (red.), op. cit., s. 55 i n.

14 Zob. J. Randsdell, Constitutive Rules and Speech-Acts Analysis, „The Journal of Philosophy" 68, 1971, nr 13, s. 385 i n.
} 
posługiwało się konstrukcją nieważności czynności karnoprocesowej ${ }^{15}$, a jedynie operowało pojęciem nieważności orzeczenia ${ }^{16}$.

Czy zatem wszystkie czynności karnoprocesowe są czynnościami, których wszystkie uchybienia rozważać możemy jedynie w płaszczyźnie ich formalizacji, a więc ujmując je jako czynności istniejące i ważne? Czy w konsekwencji moga być one de facto jedynie skuteczne albo bezskuteczne? W świetle zarysowanego ujęcia czynności konwencjonalnych, wzbogaconego o mechanizm formalizacji, wydawałoby się, że taki wniosek zasadniczo wpisuje się w doktrynalne rozważania o czynnościach karnoprocesowych, niezależnie bowiem od pojęć wykorzystywanych przez poszczególnych uczestników dyskursu naukowego, dla większości - jak się wydaje - nawet czynności określane jako nieważne były po prostu bezskuteczne ${ }^{17}$. W zasadzie nikt nie zastanawiał się specjalnie nad ich statusem ontologicznym, nie wyodrębniał wprost substratów materialnych ${ }^{18}$. Wydaje się jednak, że stwierdzenie, iż mechanizm konwencjonalizacji nie ma punktów stycznych z występujacymi na gruncie piśmiennictwa karnoprocesowego poglądami wyrażanymi w kontekście czynności procesowych, jest zbyt rygorystyczne. U niektórych autorów można bowiem zauważyć akceptację tezy, że czasami dotknięte wadami czynności prawa karnego procesowego podlegają całkowitej eliminacji - słowem, są nieważne lub nawet nieistniejace prawnie ${ }^{19}$.

Zaznaczmy, że reguły konstytutywne (reguły konwencjonalizacji) oraz reguły formalizacji czynności karnoproceso-

15 Zob. w projekcie artykułowanym do k.p.k. z 1959 r. (Kom. Kod. 167/25/1-345, niepubl.) „Znajdowały się przepisy, że nieważne miało być oświadczenie woli, które skutkiem błędu lub bezprawnego przymusu nie odpowiadało rzeczywistej woli składającego oświadczenie; to samo dotyczyłoby osoby, która skutkiem zakłócenia czynności psychicznych nie mogłaby rozpoznać znaczenia swego oświadczenia lub pokierować swoim postępowaniem. Nieznajomość przepisu prawnego byłaby bez znaczenia, chyba że wynikałaby z błędnego pouczenia o prawie przez organ działający w postępowaniu karnym. Nie byłaby nieważna czynność niezgodna jedynie z przepisem porządkowym, przepis porządkowy powinien być jednak zachowany, o ile szczególne okoliczności nie stałyby temu na przeszkodzie. Nieważne czynności procesowe nie wywoływałyby zamierzonych skutków procesowych” - W. Daszkiewicz, Prawo karne procesowe. Zagadnienia ogólne, Poznań 2001, s. 41.

${ }_{16}$ Zob. np. E. L. Wędrychowska, M. P. Wędrychowski, Nieważność orzeczeń w polskim procesie karnym, Warszawa 1999.

17 S. Śliwiński, Polski proces karny przed sqdem powszechnym, Warszawa 1959, s. 214 i n.

18 Zob. R. Kmiecik, Konwalidacja i konwersja wadliwych dowodów, „Państwo i Prawo” 1989, z. 5 , s. $91 \mathrm{i} \mathrm{n.}$

${ }^{19}$ Zob. T. Gizbert-Studnicki, O nieważnych..., s. 79; M. Cieślak, op. cit., s. 132 i n.; K. Korzan, Wyroki nieistniejace, Acta Universitatis Wratislaviensis Przegląd Prawa i Administracji 1976, t. 7, s. 185 i n.; J. Sikora, Orzeczenia nie istniejace, „Studia Cywilistyczne” 29, 1978, s. 177 i n.; J. Preussner-Zamorska, O nieważności czynności prawnej w prawie cywilnym, Warszawa 1983, s. 106 i n.; B. Bladowski, Orzeczenia nieistniejace w cywilnym postepowaniu odwoławczym, „Nowe Prawo" 1991, nr 1-3, s. 79 i n.; K. Markiewicz, Problem sentententia non existens na tle orzecznictwa Sadu Najwyższego, „Rejent” 2002, nr 12, s. 92 i n.; S. Czepita Zagadnienie orzeczeń nieistniejacych w postępowaniu cywilnym w świetle koncepcji czynności konwencjonalnych, w: idem (red.), op. cit., s. 139 i n.; idem, Teoretyczne i praktyczne aspekty zagadnienia tak zwanych wyroków nieistniejacych w postepowaniu cywilnym, w: Proces cywilny. Nauka-kodyfikacja-praktyka. Ksiega jubileuszowa dedykowana Profesorowi Feliksowi Zedlerowi, Warszawa 2012. 
wych są wyrażone w przepisach prawnych ${ }^{20}$. Dokonujac pewnej generalizacji, można powiedzieć, że reguły konstytutywne czynności karnoprocesowych zakreślone są w sposób bardzo ogólny. W ich ramach wyodrębnić możemy niektóre reguły określające: podmiot czynności konwencjonalnej, jej nazwę (konotację), warunki modalne (np. jej miejsce i czas), a także elementy przedmiotowe. To ogólne spostrzeżenie nie prowadzi do konstruktywnych wniosków, również reguły formalizacji dotyczą bowiem tych samych kategorii. W istocie bowiem granice pomiędzy regułami konstytutywnymi a regułami formalizacji są uchwytne jedynie przez ocene konsekwencji ich naruszenia. Naruszenie tych pierwszych prowadzi do stwierdzenia braku czynności, nieważności danej czynności (co nie zmienia faktu, że nadal może pozostać obarczony wadą substrat materialny tej czynności). Naruszenie zaś reguł formalizacji powoduje, że czynność karnoprocesowa jest rozpoznawana jako określona czynność karnoprocesowa, będąc czynnością wadliwą ${ }^{21}$. W tym ostatnim przypadku, przynajmniej teoretycznie, możliwa jest jej konwalidacja ${ }^{22}$.

Wyraźnie rozgraniczając reguły konstytutywne i reguły formalizacji, wbrew wstępnym intuicjom, odnajdujemy (pomimo generalnego stanowiska, że problemy dogmatyczne prawa karnego procesowego rozważane winny być w oparciu o narzędzie analizy, jakim jest formalizacja) w niektórych rozwiązaniach prawa karnego procesowego wyraźne nawiązanie do mechanizmu konwencjonalizacji. Pojawia się ono właśnie w ramach konstrukcji niedopuszczalności czynności karnoprocesowej, przede wszystkim w ujęciu, z jakim mamy do czynienia na gruncie przepisów k.p.k., a dokładniej w s y tu a cjach, w których ustawa karnoprocesowa posługuje się terminem "niedopuszczalność» w kontekście określonego zachowania się uczestnika procesu karnego. Zaznaczmy przy tym, ̇̇e „kodeksowe” ujęcie niedopuszczalności jawi się jako ściślejsze względem ujęcia doktrynalnego.

20 S. Czepita wskazuje na ścisły związek pomiędzy konotacja, a więc treścią językową nazwy danej czynności konwencjonalnej, a jej regułami konstytutywnymi, zakładając nadto, że nazwa danej czynności prawnej jest sformułowana w języku prawniczym, a więc także na podstawie kryteriów wypracowanych w doktrynie i orzecznictwie - zob. S. Czepita, Reguty..., s. 175 oraz 225.

21 Przy takim ujęciu czynność wadliwa oznacza istniejącą i ważną czynność karnoprocesowa, której wadą może być bezskuteczność (warunkowa/bezwarunkowa). W nauce procesu karnego choć najczęściej terminem wadliwość określa się wszystkie wady czynności karnoprocesowych, a więc także nieważność, niedopuszczalność - formułowane są także stanowiska nawiąujące do ujęcia wąskiego. T. Grzegorczyk, wyraźnie wskazuje, że: „czynności wadliwe to takie czynności, które są wprawdzie dopuszczalne, ale nie spełniają wszystkich stawianych im wymogów procesowych" (idem, w: T. Grzegorczyk, J. Tylman, Polskie postepowanie karne, Warszawa 2011, s. 406).

22 Sposobem konwalidacji czynności karnoprocesowej nie jest jej powtórzenie - zob. R. Kmiecik, Konwalidacja..., s. 94 i n.; W. Daszkiewicz, op. cit., s. 40. Powtórzenie czynności może mieć znaczenie z punktu widzenia ewentualnej „konwalidacji” przebiegu postępowania - zob. S. Steinborn, Konwalidacja wadliwej rozprawy oraz częściowe uchylenie wyroku w świetle bezwzględnych podstaw odwoławczych z art. 439 \& 1 k.p.k. (Na marginesie wyroku SN z 21 listopada 2001 r., III KKN 81/01), „Palestra” 2003, nr 5-6. Zob. także rozważania S. Waltosia na temat konwalidacji rzeczywistej i konwalidacji pozornej - S. Waltoś, Konwalidacja w procesie karnym, „Nowe Prawo” 1960 , z. 4, s. 494-498. 
IV. Zauważyć można także, że w nauce procesu karnego termin niedopuszczalność jest ujmowany niejednolicie, aby unaocznić postawioną tezę, pogladowo zatem wskażmy reprezentatywne stanowiska.

Rozpocznijmy od ujęcia, które chyba należałoby zakwalifikować jako ścisłe, a zgodnie z którym Stanisław Śliwiński definiował czynność niedopuszczalna jako czynność zakazaną przez prawo i przeciwstawiał ją czynności dopuszczalnej. Uznawał on, że: „Dopuszczalna jest czynność, która nie jest zabroniona przez prawo chociażby nawet była nieważna i nie wywierała żadnych skutków prawnych. [...] Czasem czynność niedopuszczalna może stać się ważna i skuteczna" 23 .

Szerzej kwestię niedopuszczalności postrzegał Leon Schaff, dla którego czynnością niedopuszczalną w procesie karnym jest nie tylko czynność zakazana, ale także nieprzewidziana w prawie karnym procesowym ${ }^{24}$.

W ujęciu Kazimierza Marszała: „[...] niedopuszczalna jest czynność procesowa, która jest zabroniona, trzeba jednocześnie podkreślić, iż zabronienie (zakaz dokonania) czynności może wynikać nie tylko z wyraźnego zakazu, ale także z braku uprawnienia, które a contrario wynika z zakresu przyznanego uprawnienia" ${ }^{25}$. Według Marszała czynnościami niedopuszczalnymi sa przede wszystkim czynności, co do których: „[...] występuje wyraźny zakaz zamieszczony w ustawie [...] 2) czynność dokonano poza zakresem przyznanych z mocy ustawy uprawnień; 3) upłyną termin prekluzyjny lub zawity; 4) czynność dokonano przez osobę nieuprawnioną lub bez wymaganego uprawnienia; 5) brak prawnych warunków danej czynności decydujaccych o jej dopuszczalności” ${ }^{26}$. Wskazany autor konstatuje, że: „[...] obowiazujący kodeks postępowania karnego nie reguluje w sposób ogólny skutków dokonania czynności mimo jej niedopuszczalności, stąd też trudno ustalić ogólną regułę w tym względzie. Do kwestii tej należy ustosunkować się w zależności od tego, czy czynność taka dokonana została przez stronę jej przedstawiciela, czy też organ prowadzący postępowanie" ${ }^{27}$. W konsekwencji Marszał stwierdza, że dokonanie przez organ procesowy czynności niedopuszczalnej skutkuje bezwzględna (a więc obarczoną wadą z art. 439 k.p.k.) albo względną (a więc dotkniętą wadą z 438 k.p.k.) wadliwością orzeczenia. Co do innych czynności organów skutki te kształtują się w różny sposób. Natomiast w przypadku dokonania czynności niedopuszczalnej przez stronę wskazany autor uznaje, iż czynność taka jest czynnością bezskuteczna.

Również zdaniem Tomasza Grzegorczyka: „Dopuszczalność czynności wiąże się z istnieniem jej ustawowych warunków, czyli z prawną możliwościa dokonania tej czynności w świetle norm karnoprocesowych. Niedopuszczalne sa zatem takie czynności, których prawo karne procesowe bądź to wyraźnie

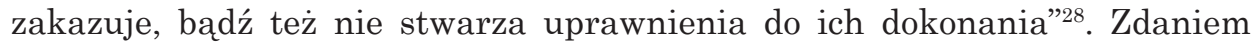

\footnotetext{
${ }^{23}$ S. Śliwiński, op. cit., s. 215.

${ }^{24}$ Zob. L. Schaff, Proces karny PRL, Warszawa 1953, s. 331.

${ }^{25}$ K. Marszał, Proces karny. Zagadnienia ogólne, Katowice 2013, s. 292.

${ }^{26}$ Ibidem, s. 292.

${ }^{27}$ Ibidem.

${ }^{28}$ T. Grzegorczyk, op. cit., s. 406.
} 
Grzegorczyka: „Czynności niedopuszczalne z założenia jednocześnie sa bezskuteczne, tj. nie mogą wywołać skutków, jaki wiąże się z daną czynnością"29.

Stanisław Waltoś akcentuje charakter konstrukcji niedopuszczalności, uznając, że: „[...] występuje ona wówczas, gdy czynność przeprowadza się mimo braku jej ustawowych warunków. Jest to wadliwość oglądana ex ante, przed dokonaniem czynności [...]. Tylko niekiedy expressis verbis ustawa stanowi, że czynność jest niedopuszczalna. Wówczas niedopuszczalność faktyczna równa się prawnej bezskuteczności czynności. W pozostałych wypadkach niedopuszczalność wynika z istoty samej czynności”. Zdaniem Waltosia: „,...] We wszystkich wypadkach, w razie postępowania odwoławczego lub kasacyjnego, powstaje domniemanie prawnie niewzruszalne, że dokonanie czynności niedopuszczalnej mogło wywrzeć wpływ na treść zaskarżonego orzeczenia, a więc domniemanie prowadzace do jego uchylenia"30.

Według Cezarego Kuleszy: „[...] nieważnością dotknięta jest niewątpliwie niedopuszczalna czynność procesowa jako dokonana wbrew zakazom ustawowym" ${ }^{31}$.

Dla Krzysztofa Woźniewskiego, źródłem niedopuszczalności czynności jest «procesowy zakaz jej dokonania»: „[...] niedopuszczalność określonego zachowania procesowego bardzo często jednakże jest wyrażona przy użyciu zwrotów $\mathrm{w}$ sensie prawnym równoznacznych z określeniem niedopuszczalny. Zwrotami takimi są także np. "nie prowadzi się«, »nie wolno«, czy użycie zdań sposobowo ograniczonych" ${ }^{32}$. Pośród czynności niedopuszczalnych Woźniewski wyodrębnia te: „Wobec których prawo nakłada dodatkowe wymogi prawne. Muszą one być spełnione, aby czynność mogła wywołać skutek prawny (tj. po upływie terminu, przez podmiot nieuprawniony). W powołanych sytuacjach ustawodawca posługuje się zwrotem "nie można» na wyrażenie zakazu określonego zachowania procesowego [...]”33. Według referowanego poglądu: „[...] oprócz wysłowionych zakazów procesowych należy przyjąc także obowiązywanie zakazów wynikajacych pośrednio z norm prawnych regulujących szeroko rozumiane warunki dokonania określonych czynności procesowych, czyli ogólne i szczególne warunki, od których uzależnione jest dokonanie czynności procesowej wywołującej zamierzone przez ustawodawcę skutki procesowe" ${ }^{34}$. Zatem i w ujęciu tego autora konsekwencje dokonania czynności karnoprocesowej niedopuszczalnej różnią się między sobą.

Interesujący pogląd przedstawił Romuald Kmiecik, przyjmując w rozważaniach na temat konwalidacji i konwersji wadliwych dowodów w procesie karnym, że niedopuszczalność $\mathrm{w}$ znaczeniu ścisłym jest rezultatem działania bezprawnego (zabronionego przez prawo procesowe). W ocenie tego autora: „Nawiązując do teorii czynności konwencjonalnych, można by przyjąć, że właśnie czynności niedopuszczalne, jako zabronione przez prawo procesowe, nie

${ }^{29}$ Ibidem, s. 406.

30 S. Waltoś, P. Hofmański, Proces karny. Zarys systemu, Warszawa 2013, s. 55.

31 C. Kulesza, w: P. Kruszyński (red), Wykład prawa karnego procesowego, Warszawa 2004, s. 226 .

${ }^{32}$ K. Woźniewski, Prawidłowość czynności procesowych w polskim procesie karnym, Gdańsk 2010 , s. 170 .

33 Ibidem, s. 171.

${ }^{34}$ Ibidem, s. 172. 
należą do żadnej kategorii czynności prawnych. Sa to czynności bezprawne i jako takie nie zawierają substratu nadającego się zarówno do konwalidacji, jak i konwersji”"35.

V. Przedstawiony powyżej skrótowy przegląd doktrynalnych ujęć konstrukcji «niedopuszczalności czynności karnoprocesowej» wyraźnie zatem daje asumpt do uznania, że termin ten w języku prawniczym rozumiany jest zwykle szerzej niż tylko w odniesieniu do sytuacji, w których ustawa wprost określa jakaśs czynność jako «ni e d op u s z c z a ln ą", choć jak wynika z powyżej dokonanego sprawozdania, niektórzy autorzy opowiadają się także za ujęciem węższym. Szerokie ujęcie «niedopuszczalności czynności karnoprocesowych» ma swoje zalety, ale też swoją cenę. Otóż w zasadzie trudno w jednolity sposób opisać jej konsekwencje procesowe, w każdym razie stanowiska zajmowane przez przedstawicieli doktryny procesu karnego w kwestii tej oceny są zróżnicowane. Wydaje się również, że skłania to także do nieco arbitralnego, by nie rzec dowolnego, posługiwania się terminem «niedopuszczalność» w odniesieniu do konstrukcji karnoprocesowych.

Tymczasem termin «niedopuszczalność czynności karnoprocesowej» jest terminem języka prawnego. Czy zatem doktrynalne ujęcia niedopuszczalności są uzasadnione w świetle kontekstów, w jakich ustawodawca posługuje się nim w tekście ustawy? Oczywiście niemożliwe jest w tym miejscu zaprezentowanie wyników szczegółowej analizy polegającej na badaniu, m.in. przez określenie kontekstu użycia i charakteru instytucji, znaczenia terminu niedopuszczalność we wszystkich wskazanych poniżej przypadkach. Spróbujmy zatem dokonać w tym względzie pewnej syntezy.

W tekście ustawy k.p.k. ustawodawca posługuje się terminem «niedopuszczalność» odnośnie do czynności podmiotów procesu karnego, m.in. w następujących artykułach: $12 \S 3 ; 65 \S 1$ pkt $1 ; 108 \S 1 ; 170 \S 1$ pkt $1 ; 171 \S 5 ; 248$ $\S 3 ; 354$ pkt $1 ; 429 \S 1 ; 498 \S 1 ; 501 ; 517$ e $\S 4 ; 524 \S 3 ; 539 ; 542 \S 5 ; 560 \S 2$; $603 \S 3 ; 604 \S 1 ; 607 \mathrm{a} ; 608 \S 3$ i $609 \S 1$ i $2 ; 610 \S 2,3,5 ; 611 \mathrm{a} \S 1,3 ; 611 \mathrm{~b}$, a po wejściu w życie 1 lipca 2015 r. także m.in. w art. $14 \S 2$ i art. 168a. Przepisy te reguluja zarówno czynności organów procesu, jak i jego stron i przedstawicieli procesowych.

W sytuacji gdy «niedopuszczalność» dotyczy czynności uczestnika niebędącego organem albo czynności zbiorowej, w której uczestniczy organ i podmiot niebędący organem (np. przesłuchanie), wydaje się, że kontekst normatywny użycia terminu "czynność niedopuszczalna» pozwala na przyjęcie tezy, że w taki właśnie sposób wyznaczona została reguła konstytutywna czynności

\footnotetext{
${ }^{35}$ Zgodnie ze spostrzeżeniem Kmiecika „W języku prawniczym, a niekiedy także w języku prawnym [...] niedopuszczalność pojmowana jest także inaczej, jako odpowiednik bezskuteczności”, przy czym Kmiecik utożsamia bezskuteczność z nieważnościa, odmiennie niż autorzy koncepcji czynności konwencjonalnych - R. Kmiecik, Konwalidacja..., s. 96; D. Karczmarska, Bezwzględne przyczyny odwoławcze a dopuszczalność konwalidacji orzeczenia, w: W. Cieślak, S. Steinborn, Profesor Marian Cieślak. Osoba, dzieło, kontynuacje, Warszawa 2013, s. 803.
} 
danego typu, choć w postępowaniu karnym pozostaje quasi-substrat materialny czynności. Możliwa wydaje się eliminacja owego rzekomego substratu materialnego, który nie został rozpoznany jako czynność danego typu. Kodeks postępowania karnego zwykle nie przewiduje jednak właściwej procedury eliminacyjnej, która czasem może mieć miejsce np. dopiero w momencie ustalania przez sąd podstawy faktycznej rozstrzygnięcia.

Pewne wątpliwości co do znaczenia terminu niedopuszczalność pojawiaja się na gruncie czynności organów - przede wszystkim decyzji procesowych. Ze względu bowiem na brak w obecnym stanie prawnym konstrukcji nieważności orzeczenia, nasuwa się pytanie, czy decyzje wydane wbrew niedopuszczalności ich wydania istnieja w procesie karnym i rodzą właściwe im skutki. Co ciekawe, ustawodawca stosunkowo rzadko operuje w k.p.k. terminem niedopuszczalność względem decyzji procesowych, tj. tylko w artykułach: $501 ; 524$ $\S 3 ; 542 \S 5 ; 604 \S 1 ; 607 \mathrm{a} ; 611$ b oraz $611 \mathrm{a} \S 3$.

Wydaje się, że we wszystkich tych przypadkach konstrukcja niedopuszczalności użyta została do określenia negatywnych przesłanek wydania określonych decyzji procesowych. Z pewnościa w przepisach tych nie są określone reguły konstytutywne czynności danego typu, orzeczenia wydane z naruszeniem tych przepisów pozostają orzeczeniami. Wydaje się, że formuła niedopuszczalności w tych sytuacjach mogłaby zostać zastapiona zwrotem «nie można». Choć niewątpliwie z perspektywy teoretycznej sygnalizowany tu problem niedopuszczalności wydania orzeczenia określonej treści wymaga jeszcze pogłębionych rozważań ${ }^{36}$.

W ramach szerokiego, doktrynalnego ujęcia niedopuszczalności najczęśsciej uznaje się, że z czynnością niedopuszczalną mamy do czynienia także wówczas, gdy ustawodawca posługuje się zwrotami wyrażajacymi formułę zakazu ${ }^{37}$ : «nie powinien», "nie można», "nie może», «nie wszczyna się», «nie wolno», «nie odbiera się», «nie stosuje się», «nie orzeka się». Zauważmy jednak, że analizując jednostki redakcyjne k.p.k. (tj. artykuły: $17 \S 1,117 \S 2$ i 3; 157 $\S 3 ; 170 \S 2 ; 171 \S 4 ; 174 ; 186 ; 189 ; 203 \S 3 ; 257 \S 1 ; 259 \S 2$ i $3 ; 295 \S 3 ; 311$ $\S 3 ; 315 \S 2$ i $3 ; 318 ; 325 \mathrm{c} ; 415 \S 5 ; 452 \S 1 ; 454 \S 1$ i $3 ; 480 \S 1 ; 517 \mathrm{f} \S 1 ; 589 \mathrm{t}$ $\S 2 ; 607 \mathrm{e} \S 1 ; 607 \mathrm{j} \S 1 ; 607 \mathrm{~s} \S 1$ ), w których zakazuje się przede wszystkim organom procesu karnego czynić użytek ze swych kompetencji (ogranicza ich kompetencje), najczęściej mamy do czynienia ze zgoła odmienną sytuacją. B e z wątpienia czynności dokonane wbrew regułom określonym w tych przepisach są istniejacymi i ważnymi czynnościami karnoprocesowymi, lecz czasem ograniczona lub wyłaczona jest ich skuteczność. Wskazane przepisy nie są źródłem reguł konstytutywnych wskazanych czynności karnoprocesowych, natomiast konstruują one elementy tych czynności, tworząc reguły ich formalizacji.

Czasem jednak mamy do czynienia z odmienna sytuacja, a mianowicie wydaje się, że użycie w k.p.k. zwrotów: «nie wolno», «nie mogą stanowić

${ }^{36}$ Zob. B. Janusz-Pohl, O wyroku..., s. 3 i n.

37 Zob. K. Woźniewski, op. cit., s. 160 i n. 
dowodu», «nie stanowią dowodu» w art. 178, art. $196 \S 2$ oraz art. 199 k.p.k. nie zmienia tego, że wskazane przepisy ustanawiaja jednak reguły konstytutywne czynności przesłuchania świadka (art. 178 i 199 k.p.k.), wydania opinii biegłego, przesłuchania biegłego (art. $196 \S 2$ i art. 199 k.p.k.).

VI. Optyka przyjęta w ramach niniejszego szkicu wydaje się obiecująca w ramachanalizy oczekujących na wejściew życie dwóch zmiandok.p.k.,tj.art. 14 $\S 2$ oraz art. 168a. Również w ich ramach wprowadzona została konstrukcja «niedopuszczalności czynności karnoprocesowej». Zgodnie bowiem z art. 14 $\S 2$ k.p.k. w brzmieniu nadanym mu nowelą z 27 września 2013 r. oskarżyciel publiczny może cofnąć akt oskarżenia do czasu rozpoczęcia przewodu sądowego na pierwszej rozprawie głównej. W toku przewodu sądowego przed sądem pierwszej instancji cofnięcie aktu oskarżenia dopuszczalne jest jedynie za zgodą oskarżonego. Ponowne wniesienie oskarżenia o ten sam czyn jest niedopuszczalne. W ramach analizy tego przepisu kwestia niedopuszczalności określonej czynności oskarżyciela publicznego pojawia się aż dwukrotnie, jednak w tym miejscu zajmiemy się tylko zdaniem ostatnim art. $14 \S 2$ k.p.k., a więc zdaniem, na mocy którego „ponowne wniesienie oskarżenia przeciwko tej samej osobie o ten sam czyn jest niedopuszczalne”. Zaznaczmy wyraźnie, że wskazany zwrot odgrywa podwójną rolę na gruncie nowej instytucji cofnięcia skargi, po pierwsze bowiem, rzutuje wprost na zmianę charakteru przesłanki procesowej, jaka jest skarga uprawnionego oskarżyciela, po drugie zaś - wyznacza regułę, której status można rozważać w płaszczyźnie jej konwencjonalizacji.

Próbujac zatem określić, jaki charakter ma wskazana reguła, zapytajmy o procesowe konsekwencje jej naruszenia. Czy wniesienie przez oskarżyciela publicznego ponownej skargi (tj. po uprzednim jej cofnięciu) w takich samych granicach podmiotowych i przedmiotowych zostanie rozpoznane jako czynność karnoprocesowa nazwana "wniesieniem aktu oskarżenia»? Wydaje się, że w zależności od przyjętych założeń odpowiedzi mogłyby być dwojakiego rodzaju. Jedni powiedzieliby, że taka czynność karnoprocesowa byłaby uznana za czynność "wniesienia aktu oskarżenia», tyle że byłaby ona bezskuteczna, a tym samym stanowisko tych autorów przesądzałoby o uznaniu reguły z art. 14 $\S 2$ k.p.k. za regułę formalizacji. Drudzy natomiast uznaliby, że czynność ta nie zostałaby rozpoznana jako karnoprocesowa czynność określana «wniesieniem aktu oskarżenia». Z tej perspektywy byłaby ona nieważna, a organ (de facto prezes sądu i sąd) nie musiałby się z nią liczyć.

W świetle przedstawionych wcześniej założeń wydaje się, że konstrukcja bardziej adekwatną do określenia charakteru reguły z art. 14 § 2 in fine jest uznanie jej za regułę konstytutywna, w tym sensie przykład ten wpisywałby się w zbiór tych sytuacji, w których ustawodawca posługuje się terminem niedopuszczalność w znaczeniu ścisłym. Wydaje się, że uznanie, iż reguła z art. 14 $\S 2$ k.p.k. jest regułą formalizacji, której naruszenie powodowałoby bezskuteczność podjętej wbrew tej regule czynności, powinno rodzić pewne obowiązki po stronie organu procesowego (sądu) w zakresie ustosunkowania się do takiej czynności oskarżyciela publicznego. Różnicą w przedstawionych ujęciach jest 
także to, że czynność, naruszająca reguły konstytutywne, nigdy (tj. od samego początku) nie była zdatna do wywołania okreśs lonych skutków, w przypadku zaś czynności bezskutecznych wydaje się, że potencjalnie czynność taka ab ovo zdatna jest do wywołania określonych skutków, jednak pewne ujawnione jej uchybienia nakazują uznać ją za czynność wadliwa (b ezskuteczna).

Jak podkreślano w doktrynie procesu karnego, niedopuszczalność czynności oceniana jest ex ante $e^{38}$, nie zaś ex post, w tym więc sensie przyjęcie w jej ramach konstrukcji reguł konstytutywnych jest bardziej naturalne. Zauważmy, że to właśnie bezskuteczność danej czynności oceniana jest ex post. Z pewnościa jednak wykorzystanie koncepcji reguł konstytutywnych (reguł konwencjonalizacji) powiązanej z konstrukcją niedopuszczalności sensu stricto czynności karnoprocesowej na gruncie wyizolowanego z treści k.p.k. przepisu prawnego może przynajmniej niektórym wydawać się dość jałowe i nieprzekładajace się wprost na rozstrzyganie kwestii praktycznych. W niniejszym szkicu podjęto jednak próbę zastosowania pewnej koncepcji niejako całościowo, przy jednoczesnej akceptacji tego, że w ramach niektórych przykładów konsekwencje jej przyjęcia są mniej bądź bardziej dyskusyjne.

Dlatego przejdźmy teraz do analizy drugiego wprowadzonego przez ustawodawcę w ramach nowelizacji z 23 września 2013 r. przepisu, tj. art. 168a k.p.k., którego interpretacja wydaje się prowadzić do zdecydowanie bardziej interesujących dla praktyki prawniczej wniosków. Zgodnie z nim niedopuszczalne jest przeprowadzenie i wykorzystanie dowodu uzyskanego dla celów postępowania karnego za pomoca czynu zabronionego, o którym mowa w art. 1 $\S 1$ k.k. ${ }^{39}$ Jedynie pokrótce wskażmy, że wykładnia zarówno tego przepisu, jak i wskazanych wcześniej innych przepisów zwiąanych z tokiem postępowania dowodowego, musi aktualnie zostać przedstawiona w innym nieco świetle, na mocy bowiem noweli z 27 września 2013 r. ustawodawca zdecydował się na zmianę formuły prowadzenia postępowania dowodowego przed sądem w taki sposób, że - ogólnie rzecz ujmujacc - zarówno inicjatywa dowodowa, jak i czynności przeprowadzania dowodów zostały niemalże w pełni przekazane stronom sporu sądowego ${ }^{40}$. Wydaje się zatem, że naturalną konsekwencją eliminacji zasady działania z urzędu w ramach postępowania dowodowego $\mathrm{w}$ stadium jurysdykcyjnym jest potrzeba rozważenia kwestii wprowadzenia do k.p.k. dodatkowych uprawnień stron postępowania w zakresie automatycznego dyskwalifikowania już w toku postępowania dowodów niedopuszczalnych. Ustawodawca ani projektodawca żadnych propozycji w tym względzie nie sformułowali.

${ }^{38}$ Zob. S. Waltoś, P. Hofmański, op. cit., s. 56.

${ }^{39} \mathrm{~W}$ doktrynie postulowano wprowadzenie regulacji uzależniającej „[...] dopuszczalność wykorzystywania nielegalnie uzyskanego dowodu rzeczowego od uprzedniego pociagnięcia do odpowiedzialności karnej właściwego funkcjonariusza publicznego, który podjął nielegalne »działania dowodowe« [...]" - R. Kmiecik, Dowód ścisty w procesie karnym, Lublin 1983, s. 96.

${ }^{40}$ Zob. P. Hofmański, Wielka reforma Kodeksu postepowania karnego, „Forum Prawnicze” 2013, nr 4, s. 9 i n.; P. Wiliński (red.). Kontradyktoryjność w polskim procesie karnym, Warszawa 2013. 
Właśnie w ramach przedstawiania tego zagadnienia pojawia się pytanie o zasadność wprowadzenia do k.p.k. konstrukcji «nieważności czynności karnoprocesowych» i procedury jej stwierdzania. Nadmieńmy, że interpretacja art. 168a k.p.k. nasuwa szereg dodatkowych wątpliwości, i to wcale niezwiązanych z ujęciem kategorii «niedopuszczalności» wyrażonej na jego gruncie ${ }^{41}$. $\mathrm{Z}$ punktu widzenia bazowej koncepcji istotne jest jednak rozstrzygnięcie tego, czy reguła wyrażona w art. 168a k.p.k. jest reguła konstytutywną czy tylko reguła formalizacji. Jak wiadomo, przyjęcie stanowiska pierwszego oznaczałoby, że dowód uzyskany i wprowadzony do procesu karnego z pogwałceniem art. 168a k.p.k. jest nieważny i w sensie prawnym nie stanowi dowodu. Przyjęcie ujęcia drugiego, a więc że reguła wyrażona w art. 168a k.p.k. jest reguła formalizacji, determinowałoby uznanie, że czynność dokonana wbrew tej regule jest bezskuteczna. Przy takim stanowisku mamy problem z ocena charakteru wytworu tej czynności, skoro bowiem sama czynność byłaby bezskuteczna, w konsekwencji nie mogłaby doprowadzić do wygenerowania jej wytworu $^{42}$. Paradoksalnie jednak, uznając czynność za bezskuteczna, w taki sam sposób kwalifikujemy jej wytwór, tj. uznajemy jego istnienie i ważność, choć twierdzimy, że jest on «bezskuteczny». Tymczasem wytwór czynności należy do odmiennej kategorii ontologicznej i nie kwalifikuje się do oceny z punktu widzenia skuteczności/bezskuteczności ${ }^{43}$. Przyjmując ujęcie drugie, moglibyśmy więc uznać, że choć opowiadamy się za bezskutecznością czynności dokonanej z pogwałceniem art. 168a k.p.k., to jednak jej wytwór (tj. środek dowodowy dostarczony za jej pośrednictwem w procesie karnym) może być kwalifikowany tylko jako istniejący lub nieistniejący/ważny i nieważny.

Z łatwością więc zauważamy, że i przy takim ujęciu nie uciekamy od kwestii nieważności, która niejako przesuwamy z czynności karnoprocesowej na jej wytwór. Choćby więc z tego powodu wydaje się, że ujęcie to jest mniej korzystne, w procesie karnym bowiem w ostatecznym rozrachunku chodzi o wytwory czynności dowodowych, wcale zaś nie o same czynności, choć te ostatnie niewątpliwie mają decydujące znaczenie dla powstania owych wytworów. Wydaje się zatem, że «niedopuszczalność» określona w art. $168 \mathrm{a}$ k. p. k. jest "niedopuszczalnościa sensu stricto», którą należy interpretować w świetle koncepcji reguł konstytutywnych czynności prawnych.

VII. Zatem analiza konstrukcji niedopuszczalności czynności karnoprocesowej musi wyraźnie wskazywać na jej ujęcie doktrynalne i kodeksowe. Już to pierwsze rozróżnienie pozwala uznać, że niedopuszczalność w ujęciu doktrynalnym jest niedopuszczalnością sensu largo, bez wątpienia konstrukcją

${ }^{41}$ By choćby tytułem przykładu wskazać tu: ujęcie koniunkcji «niedopuszczalne jest przeprowadzać i wykorzystywać», przesłanki eliminacji dowodu w postaci uzyskania go dla celów postępowania karnego za pomoca czynu zabronionego, stopnia uprawdopodobnienia tej okoliczności relatywizowanej do właściwego momentu w postępowaniu karnym, czy też ostatecznie trybu stwierdzania niedopuszczalności dowodu.

${ }^{42} \mathrm{~K}$. Twardowski, O czynnościach i ich wytworach, w: Wybrane pisma filozoficzne, Warszawa 1965, s. 219 i n.

${ }^{43}$ Ibidem, s. 224. 
bardzo pojemna, z kolei niedopuszczalność w ujęciu kodeksowym jest niedopuszczalnością sensu stricto, choć i ona nie ma jednolitego charakteru, a sam ustawodawca posługuje się nią nie zawsze konsekwentnie. Próba ustalenia, czy i ewentualnie w jakich przypadkach niedopuszczalność sensu stricto łączy się z naruszeniem reguł konstytutywnych wyodrębnianych dla czynności danego typu, oparta została na teoretycznoprawnej konstrukcji czynności konwencjonalnych w prawie, a ściślej - na wyróżnionych na jej gruncie regułach konstytutywnych. Zastosowanie tej koncepcji umożliwiło wyróżnienie dwóch zasadniczych znaczeń niedopuszczalności sensu stricto. Pierwszego, w ramach którego można uznać, że niedopuszczalność czynności określonego typu łączy się z naruszeniem reguł konstytutywnych tej czynności. Drugiego, na gruncie którego wyodrębnić można kategorię, zgodnie z która «dokonanie czynności jest niedopuszczalne, gdy», przez które następuje określenie negatywnych warunków (zwykle o charakterze merytorycznym, choć czasem i formalnym, np. temporalnym) dokonania in concreto danej czynności. Ustawodawca odwołuje się do konstrukcji niedopuszczalności w drugim znaczeniu, aby określić przesłanki wydania przez organ decyzji procesowej. W konsekwencji więc naruszenie tych reguł rozważane może być jedynie $\mathrm{w}$ oparciu o instrument formalizacji. Nadmieńmy, że czasem także dla określenia reguły konstytutywnej ustawodawca wykorzystuje inne zwroty językowe, przede wszystkim zwrot «nie stanowi dowodu». Przy tym założeniu konsekwencją dokonania czynności niedopuszczalnej będzie jej nieważność (albo nawet nieistnienie w sensie prawnym), co istotne - w procesie karnym pozostanie jednak jej substrat materialny, który nie został rozpoznany jako konwencjonalna czynność karnoprocesowa danego typu. Wnioski wynikające z niniejszej analizy przekładają się wprost na inne instytucje procesowe. W świetle powyższych rozważań jednoznacznie przedstawia się wniosek, że karnoprocesowa czynność niedopuszczalna sensu stricto nie może zostać konwalidowana ${ }^{44}$.

dr Barbara Janusz-Pohl

Uniwersytet im. Adama Mickiewicza w Poznaniu

barbaraj@amu.edu.pl

ON THE STRUCTURE OF INADMISSIBILITY OF AN ACTION IN CRIMINAL PROCEEDINGS

Summary

The paper deals with inadmissibility of actions in criminal proceedings analysed in the context of a theoretical concept of conventional actions in law. Attention has been drawn to the doctrinal (sensu largo) and legal (sensu stricto) approach to the inadmissibility of an action in criminal proceedings. Based on the above concept, an attempt has been made to establish whether inadmissibility sensu stricto is related to the infringement of the constitutive rules isolated for individual actions in criminal proceedings. Two basic definitions of the term inadmissibility of an action in criminal proceeding sensu stricto have been proposed. The analysis presented in the paper has been verified against inter alia, the institutions introduced by virtue of amendments to the Code of Criminal Procedure of 27 September as provided in its Articles14 $\S 2$ and 168a.

${ }^{44}$ Por. S. Waltoś, op. cit., s. 495. 
Copyright of Journal of Law, Economics and Sociology is the property of Faculty of Law and Administration of Adam Mickiewicz University in Poznan and its content may not be copied or emailed to multiple sites or posted to a listserv without the copyright holder's express written permission. However, users may print, download, or email articles for individual use.

Właścicielem praw autorskich do „Ruchu Prawniczego, Ekonomicznego i Socjologicznego” jest Wydział Prawa i Administracji Uniwersytetu im. Adama Mickiewicza w Poznaniu. Zawartość czasopisma nie może być kopiowana, przesyłana do innych stron internetowych bądź zamieszczana na blogach bez pisemnej zgody wydawcy. Niemniej artykuły można drukować, kopiować lub przesyłać w formie elektronicznej na własny użytek. 